\title{
Estimation of correlation coefficient study of some quantitative traits in wheat
}

Shyam Chitralekha*, P.K. Chandrakar, N.K. Rastogi, Umakant Banjare and Manoj Densena

Department of Genetics and Plant Breeding, Indira Gandhi Krishivishwavidyalaya, Raipur (C.G.), India.

Received: 1/16/2018; Revised: 1/23/2018; Accepted: 1/30/2018

\begin{abstract}
Wheat is the world's most important crop that excels all other cereal crops both in area and production, thereby providing about 20.0 per cent of total food calories for the people of the world. The experiment was conducted at Research Farm, IGKV, Raipur during Rabi 2013-14. Chhattisgarh is located in the east - central part of the country between $17^{\circ} 14^{\prime} \mathrm{N}$ and $24^{\circ} 45^{\prime} \mathrm{N}$ latitudes and $73^{\circ} 30^{\prime} \mathrm{E}$ and $84^{\circ} 15^{\prime} \mathrm{E}$ longitudes, whereas Raipur the capital of the Chhattisgarh state, lies at $21^{\circ} 16^{\prime} \mathrm{N}$ latitude and $81^{\circ} 36^{\prime} \mathrm{E}$ longitude with an altitude of 289.60 meters above sea level. All Twenty two genotypes were grown in Randomized Block Design with three replications. Correlation studies give a clear picture of characters association which is generally due to linkage, pleiotrophy, physiological association in developmental and biochemical pathway The phenotypic and genotypic correlations were determined among seed yield and its components in possible character combinations. In Correlation coefficient analysis, seed yield per plant exhibited highly significant positive correlations with number of seeds per spike and number of seeds per plant at both genotypic and phenotypic levels, whereas number of seeds per spikelet at the genotypic level.
\end{abstract}

Keywords: Correlation coefficient, yield components, variability, wheat

\section{Introduction}

Wheat is the world's most important crop that excels all other cereal crops both in area and production, thereby providing about 20.0 per cent of total food calories for the people of the world. Nearly $95 \%$ of wheat grown today is hexaploid, used for the preparation of bread and other baked products (Debasis and Khurana, 2001). The husk bran and germ are rich sources of vitamins, minerals and protein (David and Adams, 1985). Since ages, wheat has been playing an important role in the economy several countries (Singh et al., 2010).Globally, the total area under cultivated of wheat is 227 million hectares, production of wheat is 654 million metric tonnes and the productivity was recorded as 3 tonne per hectare during 20122013 (Anonymous, 2014 a). India also has the larger area under wheat. About 90 percent of total wheat production is contributing by five states viz., Uttar Pradesh, Punjab, Haryana, Madhya Pradesh and Rajasthan. The other wheat producing states are Bihar, Gujarat, Jammu and Kashmir, Maharashtra, West Bengal and Chhattisgarh. In India the area, production and productivity of this crop is 29.8 million hectares, 93.90 million metric tonne and 2.96 tonnes per hectare, respectively during 20122013 (Anonymous, 2014 b). The development of high yielding wheat cultivars is the main objective of any breeding programs in the world (Ehdaie and Waines, 1989). Identification of better genotypes with desirable traits and their subsequent use in breeding program and establishment of suitable selection criterion can helpful for successful

\footnotetext{
*Corresponding Author:

Chitralekha Shyam,

Department of Genetics and Plant Breeding,

Indira Gandhi Krishivishwavidyalaya,

Raipur (C.G.), India.

E-mail: shyamchitralekha@gmail.com
}

Varietals improvement program. Analysis of variability among the traits and the association of a particular character in relation to other traits contributing to yield of a crop would be great importance in planning a successful breeding program (Mary and Gopalan, 2006). Evolution of varieties with high yield potential accompanied with desirable combination of traits has always been the major objective of wheat breeding programme. Wadington et al., (1986) reported that 1,000 grain weight was reduced slightly in modern high grain number cultivars. Yield is one such character that results due to the actions and interactions of various component characters (Grafius, 1960). It is also widely recognised that genetic architecture of yield can be resolved better by studying its component characters. This enables the plant breeder to breed for high yielding genotypes with desired combinations of traits. The correlations are very important in plant breeding, because of its reflection in dependence degree between two or more traits. If there is genetic correlation between traits, in the case of direct selection of one trait can cause change in other trait. Correlations between traits are depending of genetic and environmental factors (Falconer, 1981). Environmental conditions can variability, not only of some trait but interrelationship between its. The objective of this study was to establish the inter-relationship of various wheat components among themselves and with yield. Correlation are very important in plant breeding, because of its Correlation is useful in disclosing the magnitude and direction of the

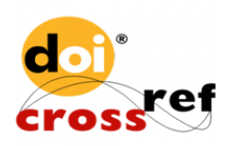


relationship between various yield contributing traits and yield. Positive correlation between desirable traits are supposed to be favourable and help to breeder in selection whereas, negative correlations hinders the recovery of the combinations in both characters. Correlation studies provide a better understanding of the association of different characters with grain yield (Dixet and Dubey, 1984).

\section{Materials and Methods}

Twenty two wheat genotypes including check varieties were used in this study. All the twenty two genotypes were grown in Randomized Block Design with three replications during Rabi 2013-14 at the Instructional cum Research Farm, Indira Gandhi Krishi Vishwavidyalaya, Raipur. Chhattisgarh is located in the east - central part of the country between $17^{\circ} 14^{\prime} \mathrm{N}$ and $24^{\circ} 45^{\prime} \mathrm{N}$ latitudes and $73^{\circ} 30^{\prime} \mathrm{E}$ and $84^{\circ} 15^{\prime} \mathrm{E}$ longitudes, whereas Raipur the capital of the Chhattisgarh state, lies at $21^{\circ} 16^{\prime} \mathrm{N}$ latitude and $81^{\circ} 36^{\prime} \mathrm{E}$ longitude with an altitude of 289.60 meters above sea level. In each replication twenty two treatments were grown in 10 rows, $5 \mathrm{~m}$ long and $20 \mathrm{~cm}$ apart. Five randomly selected plants from each treatment were tagged for recording the observations on the following characters, viz., Days to $50 \%$ flowering, Days to maturity, Plant height, Number of tillers per plant, Spike length, Number of spikelets per spike, Number of seeds per spikelet, Number of seeds per spike, Number of seeds per plant, 1000-seed weight, Seed yield per plant, Biological yield per plot, Seed yield per plot and Harvest Index. The correlation coefficients were worked out to determine the degree of association of a character with yield and also among the yield components. The phenotypic and genotypic correlations were determined among seed yield and its components in all possible character combinations. Genotypic and phenotypic correlations were calculated by using the formula given by Weber and Moorthy, 1952; Miller (1958). Genotypic correlations were computed using variance and co-variances as suggested by Johnson et al., (1955). Phenotypic correlation was calculated by the formula suggested by Al-Jibouri et al., (1958)

\section{Results and Discussion}

\section{Correlation coefficient analysis}

Correlation studies give a clear picture of characters association which is generally due to linkage, pleiotrophy, physiological association in developmental and biochemical pathway. Though, the linkage is a cause of transient correlations particularly in population derived from crosses between two species. Pleiotrophy is simply a property of a gene whereby it affects two or more characters, so that if the gene is segregating it causes variations in those characters. The characters which are correlated are of much interest since change in one character influenced the other one. The phenotypic and genotypic correlations were determined among seed yield and its components in all possible character combinations.

\section{Genotypic correlation analysis}

Genotypic correlations were determined among seed yield and its components in all possible character combinations and are presented in Table 1. Days to $50 \%$ flowering exhibited significant positive correlation with days to maturity (0.778), whereas, significant negative correlation with number of seeds per spikelet (-0.733), number of seeds per plant $(-0.554)$, seed yield per plant ($0.448)$ and number of seeds per spike (-0.424). Days to maturity had significant positive correlation with number of spikelets per spike (0.500), whereas, significant negative correlation with number of seeds per spikelet (-0.735) and seed yield per plant (0.508). Plant height exhibited significant positive correlation with number of tillers per plant (0.502) and spike length (0.842), whereas, significant negative correlation with harvest index (-1.030), seed yield per plot (-0.892), biological yield per plot (- 0.774), seed yield per plant (-0.746), number of seeds per plant (-0.642), 1000-seed weight (-0.573). Number of tillers per plant showed significant positive correlation with spike length (0.790), whereas, significant negative correlation with 1000 seed weight (-0.698) and harvest index (-0.649). Spike length had significant negative correlation with harvest index (- 0.826), 1000-seed weight (0.782 ) and seed yield per plot (-0.539). Number of spikelets per spike had significant negative correlation with biological yield per plot (-0.711), seed yield per plot (0.569) and seed yield per plant (0.492). Number of seeds per spikelet exhibited significant positive correlation with number of seeds per spike (0.487) and seed yield per plant (0.629). Number of seeds per spike showed significant positive correlation with number of seeds per plant (0.801) and seed yield per plant (0.726), whereas, significant negative correlation with 1000-seed weight (-0.424). Number of seeds per plant exhibited significant positive correlation with seed yield per plant $(0.877)$, biological yield per plot $(0.730)$, seed yield per plot (0.824) and harvest index (0.794). 1000-seed weight showed significant positive correlation with harvest index (0.700). Seed yield per plant had significant positive correlation with biological yield per plot (0.764), seed yield per plot (0.813) and harvest index (0.673). Biological yield per plot exhibited significant positive correlation with seed yield per plot (0.980) and harvest index (0.816). Seed yield per plot had significant positive correlation with harvest index (0.919). Similar finding were reported by Kumar et al., (2013), Nukasani et al., (2013) and and Keddam et al., (2014). 
Table 1. Genotypic correlation coefficients among different yield traits in wheat

\begin{tabular}{|c|c|c|c|c|c|c|c|c|c|c|c|c|c|}
\hline & $\begin{array}{l}\text { Days to } \\
\text { maturity }\end{array}$ & $\begin{array}{l}\text { Plant } \\
\text { height } \\
(\mathrm{cm})\end{array}$ & $\begin{array}{l}\text { No. of } \\
\text { tillers } \\
\text { per } \\
\text { plant }\end{array}$ & $\begin{array}{l}\text { Spike } \\
\text { length } \\
(\mathrm{cm})\end{array}$ & $\begin{array}{l}\text { No. of } \\
\text { spikelets } \\
\text { per spike }\end{array}$ & $\begin{array}{l}\text { No. of } \\
\text { seeds } \\
\text { per } \\
\text { spikelet }\end{array}$ & $\begin{array}{l}\text { No. of } \\
\text { seeds } \\
\text { per } \\
\text { spike }\end{array}$ & $\begin{array}{l}\text { No. of } \\
\text { seeds } \\
\text { per } \\
\text { plant }\end{array}$ & $\begin{array}{l}1000 \\
\text { seed } \\
\text { weight } \\
(\mathrm{g}) \\
\end{array}$ & $\begin{array}{l}\text { Seed } \\
\text { yield per } \\
\text { plant }(g)\end{array}$ & $\begin{array}{l}\text { Biological } \\
\text { yield per } \\
\text { plot (g) }\end{array}$ & $\begin{array}{l}\text { Seed yield } \\
\text { per plot } \\
\text { (g) }\end{array}$ & $\begin{array}{l}\text { Harvest } \\
\text { index } \\
(\%)\end{array}$ \\
\hline Days to $50 \%$ flowering & $0.778^{* *}$ & 0.152 & 0.025 & -0.091 & 0.181 & $-0.733^{* *}$ & $\overline{0.424 *}$ & $-0.554 * *$ & -0.077 & $-0.448^{*}$ & -0.341 & -0.340 & -0.161 \\
\hline Days to maturity & & 0.406 & 0.260 & 0.325 & $0.500^{*}$ & $-0.735^{* *}$ & -0.059 & -0.409 & -0.418 & $-0.508^{*}$ & -0.364 & -0.395 & -0.344 \\
\hline Plant height $(\mathrm{cm})$ & & & $0.502^{*}$ & $0.842^{* *}$ & 0.363 & 0.129 & -0.150 & $-0.642 * *$ & $-0.573^{* *}$ & $-0.746^{* *}$ & $-0.774 * *$ & $-0.892^{* *}$ & $-1.030^{* *}$ \\
\hline No. of tillers per plant & & & & $0.790 * *$ & -0.267 & 0.327 & 0.275 & -0.049 & $-0.698^{* *}$ & -0.083 & -0.346 & -0.410 & $-0.649 * *$ \\
\hline Spike length $(\mathrm{cm})$ & & & & & 0.140 & 0.185 & 0.328 & -0.147 & $-0.782^{* *}$ & -0.374 & -0.399 & $-0.539 * *$ & $-0.826^{* *}$ \\
\hline No. of spikelets per spike & & & & & & -0.203 & 0.051 & -0.373 & -0.263 & $-0.492^{*}$ & $-0.711 * *$ & $-0.569 * *$ & -0.347 \\
\hline No. of seeds per spikelet & & & & & & & $0.487^{*}$ & 0.408 & -0.077 & $0.629 * *$ & 0.303 & 0.171 & -0.319 \\
\hline No. of seeds per spike & & & & & & & & $0.801^{* *}$ & $-0.424 *$ & $0.726^{* *}$ & 0.332 & 0.353 & 0.132 \\
\hline No. of seeds per plant & & & & & & & & & 0.105 & $0.877 * *$ & $0.730^{* *}$ & $0.824 * *$ & $0.794 * *$ \\
\hline 1000 seed weight (g) & & & & & & & & & & 0.182 & 0.272 & 0.399 & $0.700^{* *}$ \\
\hline Seed yield per plants (g) & & & & & & & & & & & $0.764^{* *}$ & $0.813^{* *}$ & $0.673^{* *}$ \\
\hline Biological yield per plot $(\mathrm{g})$ & & & & & & & & & & & & $0.980 * *$ & $0.816^{* *}$ \\
\hline Seed yield per plot (g) & & & & & & & & & & & & & $0.919 * *$ \\
\hline
\end{tabular}

Table 2. Phenotypic correlation coefficients among different yield traits in wheat

\begin{tabular}{|c|c|c|c|c|c|c|c|c|c|c|c|c|c|}
\hline & $\begin{array}{l}\text { Days to } \\
\text { maturity }\end{array}$ & $\begin{array}{l}\text { Plant } \\
\text { height } \\
(\mathrm{cm})\end{array}$ & $\begin{array}{l}\text { No. } \\
\text { of } \\
\text { tillers } \\
\text { per } \\
\text { plant }\end{array}$ & $\begin{array}{l}\text { Spike } \\
\text { length } \\
(\mathrm{cm})\end{array}$ & $\begin{array}{l}\text { No. of } \\
\text { spikelets } \\
\text { per } \\
\text { spike }\end{array}$ & $\begin{array}{l}\text { No. of } \\
\text { seeds } \\
\text { per } \\
\text { spikelet }\end{array}$ & $\begin{array}{l}\text { No. } \\
\text { of } \\
\text { seeds } \\
\text { per } \\
\text { spike }\end{array}$ & $\begin{array}{l}\text { No. of } \\
\text { seeds } \\
\text { per } \\
\text { plant }\end{array}$ & $\begin{array}{l}1000 \\
\text { seed } \\
\text { weight } \\
(\mathrm{g})\end{array}$ & $\begin{array}{l}\text { Seed } \\
\text { yield } \\
\text { per } \\
\text { plant } \\
\text { (g) }\end{array}$ & $\begin{array}{l}\text { Biological } \\
\text { yield per } \\
\text { plot }(\mathrm{g})\end{array}$ & $\begin{array}{l}\text { Seed } \\
\text { yield } \\
\text { per } \\
\text { plot } \\
\text { (g) }\end{array}$ & $\begin{array}{l}\text { Harvest } \\
\text { index } \\
(\%)\end{array}$ \\
\hline Days to $50 \%$ flowering & $0.755^{* *}$ & 0.147 & 0.035 & -0.082 & 0.128 & $-0.426^{*}$ & 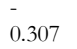 & $-0.489 *$ & -0.072 & -0.295 & -0.265 & -0.287 & -0.084 \\
\hline Days to maturity & & 0.356 & 0.163 & 0.276 & 0.306 & -0.393 & $\overline{0} .056$ & -0.373 & -0.409 & -0.351 & -0.287 & -0.330 & -0.165 \\
\hline Plant height $(\mathrm{cm})$ & & & 0.406 & $0.632^{* *}$ & 0.260 & 0.004 & $\overline{0} .075$ & $-0.490^{*}$ & $-0.517^{*}$ & -0.403 & $-0.504 * *$ & $\overline{0.713^{* *}}$ & $-0.537^{* *}$ \\
\hline No. of tillers per plant & & & & $0.493^{*}$ & 0.018 & 0.129 & 0.287 & -0.024 & $-0.470^{*}$ & 0.258 & -0.045 & -0.257 & -0.364 \\
\hline Spike length $(\mathrm{cm})$ & & & & & 0.238 & 0.208 & 0.320 & -0.110 & -0.693 & -0.133 & -0.266 & -0.349 & -0.274 \\
\hline No. of spikelets per spike & & & & & & 0.096 & 0.273 & -0.160 & -0.172 & -0.048 & -0.210 & -0.283 & -0.194 \\
\hline No. of seeds per spikelet & & & & & & & 0.352 & 0.232 & -0.073 & 0.360 & 0.224 & 0.127 & -0.099 \\
\hline No. of seeds per spike & & & & & & & & $0.591 * *$ & 0.343 & $0.538^{* *}$ & 0.265 & 0.272 & 0.086 \\
\hline No. of seeds per plant & & & & & & & & & 0.079 & $0.589 * *$ & $0.553^{* *}$ & $0.596^{* *}$ & 0.290 \\
\hline 1000 seed weight $(\mathrm{g})$ & & & & & & & & & & 0.077 & 0.191 & 0.319 & 0.327 \\
\hline Seed yield per plant (g) & & & & & & & & & & & $0.571^{* *}$ & $0.570^{* *}$ & 0.239 \\
\hline Biological yield per plot $(\mathrm{g})$ & & & & & & & & & & & & 0.771 & 0.085 \\
\hline Seed yield per plot (g) & & & & & & & & & & & & & $0.680^{* *}$ \\
\hline
\end{tabular}

\section{Phenotypic correlation analysis}

Phenotypic correlations were determined among seed yield and its components in all possible character combinations and are presented in Table 2. Positive correlation between desirable traits are supposed to be favourable and help to breeder in selection whereas, negative correlations hinders the recovery of the combinations in both characters. Days to $50 \%$ flowering exhibited significant positive correlation with days to maturity $(0.755)$, whereas, significant negative correlation with number of seeds per spikelet $(-0.426)$ and number of seeds per plant (-0.489). Days to maturity showed positive and negative correlations which all were nonsignificant. Plant height had significant positive correlation with spike length (0.632), whereas, significant negative correlation with seed yield per plot (-0.713), harvest index (-0.537), 1000-seed weight $(-0.517)$, biological yield per plot $(-0.504)$ and number of seeds per plant (-0.490). Number of tillers per plant exhibited significant positive correlation with spike length (0.493), whereas, significant negative correlation with 1000 -
Seed weight (-0.470). Spike length, Number of spikelets per spike and number of seeds per spikelet showed positive and negative correlations which all were nonsignificant whereas, number of seeds per spike had significant positive correlation with number of seeds per plant (0.591) and seed yield per plant (0.538). Number of seeds per plant had significant positive correlation with seed yield per plant (0.589), biological yield per plot (0.553) and seed yield per plot (0.596). Whereas, 1000-seed weight showed positive correlations which all were nonsignificant. Seed yield per plant had significant positive correlation with biological yield per plot (0.571) and seed yield per plot (0.570). While biological yield per plot showed positive correlations which all were nonsignificant. Seed yield per plot exhibited significant positive correlation with harvest index (0.680). Present results confirms the finding of previous workers Majumdar et al., (2008), Singh et al., (2012), Kumar et al., (2013) and Kaddem et al., (2014). 


\section{References}

1. Al-Jibouri, H.A., Miller, A.R. and Robinson, H.F. 1958. Genotypic and environmental variances and covariances in upland cotton crosses of interspecific origin. J. of Agron,. 50: 633-637.

2. Ali, Y., Atta, B.M., Akhter, J., Monneveux, P. and Lateef, Z. 2008. Genetic variability, association and diversity studies in wheat (Triticum aestivum L.) Germplasm. Pak. J. Bot., 40(5): 2087-2097.

3. Anonymous, 2014 a. FAO STAT and IGC Report, pp-1-3.

4. Anonymous, 2014 b. Department of Economics and Statistics, Govt. of India.

5. David, G. and Adams, P. 1985. Crops of the Drier Regions of the Tropics Longman Group. pp 96-98.

6. Debasis, P. and Khurana, P. 2001. Wheat biotechnology: A minireview. E.J.B: 0717-3458.

7. Dewey, D.R. and Lu, K.H. 1959. A Correlation and path coefficient analysis of component of crested wheat grass seed production. Agron. J., 51: 515-518.

8. Dixet, P. and Dubey, D.K. 1984. Path analysis in lentil (Lens culinaris Med.). Lens Newsletter, 11: 1517.

9. Ehdaie, B., Waines J.G. 1989. Genetic variation, heritability, and path-analysis in landraces of bread wheat from southwestern Iran. Euphyt. 41: 183-190.

10. Falconer, D.S.1981. Introduction to quantitative genetics. Longman Inc. London and New York.

11. Grafius, J.E. 1960. Does overdominance exist for yield in corn? Agron. J., 52: 361.

12. Johnson, H.W., Robinson, H.F. and Comstock, R.E. 1955. Genotypic and phenotypic correlations and their implication in selection. Agron., J., 47: 477-483.

13. Keddem, W.K., Markar, S. and Lavanya G.R. 2014. Investigation of genetic variability and correlation analysis of wheat (Triticum aestivum L.) genotypes for grain yield and its component traits. Eu. Aca. Res., 2(5): 2286-4822.
14. Kumar, B., Singh, C.M. and Jaiswal, K.K. 2013. Genetic variability association and diversity studies in bread wheat (Triticum aestivum L.). An International j. of life Sci., (1): 143-147.

15. Majumder, D.A.N., Shamsuddin, A.K.M., Kabir, M.A. and Hassan, L. 2008. Genetic variability, correlated response and path analysis of yield and yield contributing traits of spring wheat. J. Bangladesh Agril. Univ., 6(2): 227-234.

16. Mary, S.S., Gopalan, A. 2006. Dissection of genetic attributes yield traits of fodder cowpea in F3and F4. J. Applied Sci. Res., 2(10): 805-808.

17. Miller, P.A., Williams, J.E., Robinson, H.F. and Comstock, R.E. 1958. Estimates of variance and covariance in upland cotton and their implications in selection. Agron J., 50: 126-131.

18. Nukasani, V., Potdukhe, N.R., Bharad, S., Deshmukh, S. and Shinde, S.M. 2013. Genetic variability, correlation and path analysis in wheat. $J$. of Wheat Res., 5(2): 48-51.

19. Singh, B.N., Vishwakarma, S.R. and Singh, V.K. (2010). Character Association and Path Analysis In Elite Lines of Wheat (Triticum aestivum L.). Plant Archi., 10(2): 845-847.

20. Singh, G., Singh, M.K., Saharn, M.S., Singh, C., Tyagi, B.S. and Sharma, I. 2012. Genetic analysis and trait association in two double haploid populations of bread wheat (Triticum aestivum L.). J. Wheat res., 4(1): 49- 54

21. Wadington, S.R., Ranson, J.K., Osmazi, M. and Saundari, O.A. (1986). Improvement in yield potential of bread wheat adapted to North West Mexico. Crop. Sci., 26(5): 998-1000.

\section{Cite this article as:}

Shyam Chitralekha, P.K. Chandrakar, N.K. Rastogi, Umakant Banjare and Manoj Densena. Estimation of correlation coefficient study of some quantitative traits in wheat. Annals of Plant Sciences 7.2 (2018) pp. 20782081.

do $\mathrm{http}$ ///dx.doi.org/10.21746/aps.2018.7.2.17 